\title{
地震信頼性解析に基づく非線形粘性ダンパーを有する 免震構造物の性能設計について \\ PERFORMANCE BASED DESIGN OF BASE ISOLATED BUILDING WITH NON-LINEAR VISCOUS DAMPER BASED ON SEISMIC RELIABILITY ANALYSIS
}

\author{
中川 肇*, 浅野 幸一郎** \\ Hajime NAKAGAWA and Koichiro ASANO
}

\begin{abstract}
This paper presents the performance based parameter analysis of base isolated building with non-linear viscous damper under Tokachioki type (2003) and Niigata-ken Chuuetsu type (2004) random earthquake excitations. From the three viewpoints of seismic reliability, preservation of seismic safety and improvement of structural comfort, the optimum parameter on the base isolation interface is determined in such a way that the responses of base isolated structural system with linked damper agree with the response demanded by the structural designer. The optimality of the parameter is discussed for the performance demanded coefficient, some random earthquake excitation models, the fundamental period of base isolated building and the non-stationary random response.
\end{abstract}

Keywords: $\quad$ Performance based design, Seismic Reliability, Long natural period earthquake excitation,

Seismic safety, Structural comfort, Optimum parameter

性能設計，地震信頼性，長周期地震動，耐震安全性，居住性，最適パラメータ

\section{1. 序}

1995 年の兵庫県南部地震以後、M7クラスの巨大地震が日本各地、 海外で発生している。2003 年 9 月 26 日午前 4 時 50 分、釧路沖を震 源とする M8.0の十勝沖地震が、2004 年 10 月 23 日午後 5 時 56 分、 新潟県中越地方を震源とする M6.8 の新潟県中越地震が発生し、建 築・土木構造物に甚大な被害を六した。十勝沖地震はプレート境界 地震で、苫小牧市は不整形な堆積盆地上に位置していたために、継 続時間が長く、長周期成分を多く含む摇れを観測している。所謂、 「長周期地震動」の存在が確認された。一方、新潟県中越地震での 震源地付近は活褶曲と呼ばれる地形で、内陸活断層破壊で生じた地 震で、兵庫県南部地震に比較的類似している。従って、日本は「地 震活動期にある」と言っても過言ではない。

海外では、2004 年 12 月 26 日午前 9 時 58 分（日本時間）、スマト ラ島西方沖を震源とする M9.0のスマトラ沖地震が発生し、インドネ シアなどの東南アジア、東アフリカ諸国の 13 力国で死者 16 万人以 上の被害を齊した。スマトラ沖地震はインド・オーストラリアプレ ートがユーラシアプレートの沈み込みにより発生したプレート境界 地震で、高さ $11 \mathrm{~m}$ の巨大津波が発生し、時速 $720 \mathrm{~km}$ でインド洋を横 断し、壊滅的な被害を六柰したと推定される。
大地震時の構造物の損傷・被害軽減と倒壊回避を目指して、免震・ 制震構造の適用の必要性が益々増大している。しかし、免震構造が 経験したことがない、過大な地震入力（以下、過大入力）に対する 検討は既往の研究 ${ }^{1), 2)}$ で行われているが、過大入力或いは長周期地震 動を受けた場合の免震構造物の挙動及び免震装置の過大変形を制御 する方法について検討を加えることは現段階での重要な研究課題で ある。筆者は、既往の研究 ${ }^{3)}$ 「ランダム地震入力を受ける連結制震 ダンパーを有する 2 棟免震構造物の性能指定型設計」において、免 震装置の過大変形を制御し、かつ上部構造物の加速度応答を構造設 計者が指定する応答に留める性能指定型設計法を確率論的地震応答 解析に基づき提案した。

本論では、まず、十勝沖地震時の苫小牧市（以下、Tomakomai 型） と新潟県中越地震時の小千谷市（以下、Ojiya 型）での観測波形を基 に、非定常確率入力地震動モデルを構築する。次いで、過大入力は 現今の免震構造評定で採用されている「極めて稀に発生する地震動」 の 1.25 倍つまり、最大速度 $100 \mathrm{~cm} / \mathrm{s}$ と定義し、過大ランダム入力及 び長周期型ランダム入力を受ける免震構造の最適設計法を筆者らが かつて開発した応答を規範とする最適化手法 ${ }^{3) \sim 5)}$ に加えて、地震信 頼性理論に基づき開発する。本論の様に、地震信頼性解析をベース
* 明石工業高等専門学校建築学科 講師 ·博士 (工学)

** 関西大学工学部建築学科 教授. 工博
Lecturer, Dept. of Architecture, Akashi National College of Technology, Dr. Eng. Prof., Dept. of Architecture, Faculty of Engineering, Kansai University, Dr. Eng. 
にした免震構造の最適設計は既往の研究において全くなく、筆者ら が一貫して論じている確率論的地震応答解析に新たな展望を与える ものと考えている。

\section{2. 解析モデル}

本論の地震入力モデルは、確率論的地震入力（以下、ランダム地 震入力）を想定し、図 1 に示寸基盤へのホワイトノイズ過程 $\ddot{w} に$ 表 層地盤の増幅特性を考慮し地震動の卓越振動数 $\omega_{g}$ 、形状係数 $h_{g}$ で 規定させる線形フィルターの通過過程で得られるノンホワイトラン ダム過程 ${ }^{6)}$ である。

構造物モデルは、本論では 2 種類を想定している。BIS モデルは 最下層に積層ゴムと鋼棒ダンパーを設置する免震層と上部構造とし て弹性剛性 $r_{i} k_{i}$ 、塑性剛性 $\left(1-r_{i}\right) k_{i}$ 及び粘性減衰係数 $c_{i}$ で規定され る弹塑性フレームを持つ免震構造物モデルであり、一方、BISNVモ デルは BIS モデルの免震層に非線形粘性ダンパー（以下、NV ダン パー）を付加したモデルである。夫々のモデルの概念図を図 1 に示 す。図中の $m_{i}, u_{i}, c^{\prime}$ は任意 $\mathrm{i}$ 層のフレームの質量、層間変位及び $\mathrm{NV}$ ダンパーの粘性减衰係数で、 $y_{i}$ は Bi-linear 型履歴特性を構成するク 一ロン素子の層間変位である。

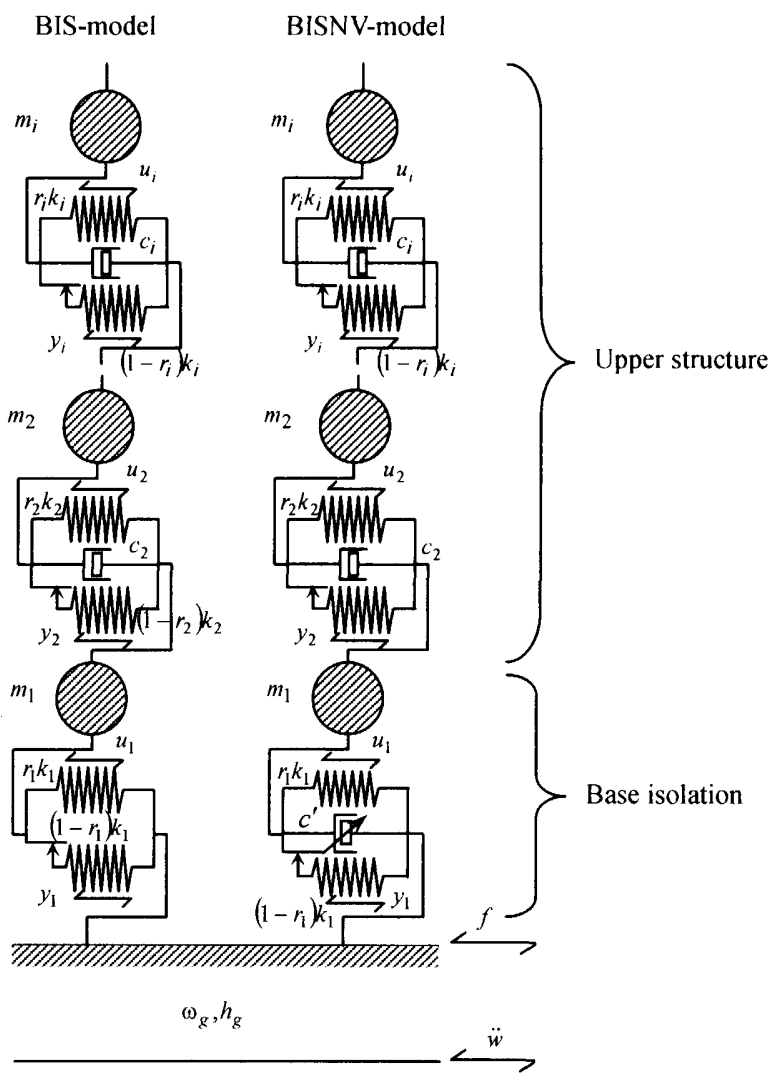

図 1 免震系モデル

\section{3. 非定常ランダム入力モデルの構築}

3.1 非定常ランダム入力のパラメータ評価

非定常ランダム入力モデルのパラメータ評価法は既往の文献 6)に 示されており、ここでは、その評価法は簡単に述べることにする。 詳細は文献 6)を参照されたい。

一般に地震入力波形 $f(\tau)$ の非定常スペクトルは次式のように表
現できる。

$$
S_{f}(\omega, t)=\frac{1}{T_{d}}\left|\int_{t-\frac{t_{d}}{2}}^{t+\frac{t_{d}}{2}} f(\tau) e^{-i \omega \tau} d \tau\right|^{2}
$$

ここで、 $T_{d}$ は非定常スペクトル計算のウインドウ幅であり、(1)式に 対応する非定常スペクトルモーメントは、次式のように定義する。

$$
\lambda_{j}(t)=\int_{0}^{\infty} \omega^{j} S_{f}(\omega, t) d \omega
$$

ここで、 $j=0,1,2$ であり、地震入力モデルを非定常なパラメータを もつ 1 質点線形フィルターの出力過程とする。本論では、金井一田 治見モデル 7)（以下、KT モデル）を採用する。ランダム入力の非定 常パラメータ $\omega_{g}, h_{g}$ は、(3)式に示す $\mathrm{KT}$ モディによるスペクトルモ ーメント $\bar{\lambda}_{j}(t)$ が(2)式に等值することにより求める。

$$
\bar{\lambda}_{j}(t)=\int_{0}^{\infty} \omega^{j} \frac{4 h_{g}^{2} \omega_{g}^{2} \omega^{2}+\omega_{g}^{4}}{\left(\omega_{g}^{2}-\omega^{2}\right)^{2}+4 h_{g}^{2} \omega_{g}^{2} \omega^{2}} S_{0} d \omega
$$

また、地震入力の振幅包絡線関数 $\sigma_{f}(t)$ は次式のように与えられる。

$$
\sigma_{f}^{2}(t)=\frac{1}{\pi} \int_{0}^{\infty} S_{f}(\omega, t) d \omega=\frac{1}{\pi} \lambda_{0}
$$

\section{2 非定常ランダム入カモデルの数値計算例}

本論では、Tomakomai 型及び Ojiya 型の非定常ランダムパラメー 夕を作成する。図 2、3 は苫小牧市、小千谷市で観測された地震波形 とそのフリーエスペクトルを示している。図 3 より、十勝沖地震の 卓越振動数は $0.29 \mathrm{~Hz}$ でやや長周期であるが、新舄県中越地震では $1.44 \mathrm{~Hz}$ であることが判る。図4には、3.1節を基に計算した Tomakomai 型、Ojiya 型非定常ランダム入力モデルのパラメータが描かれている。

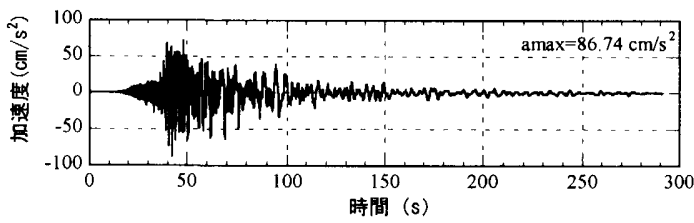

(a) 十勝沖地震苫小牧市 NS

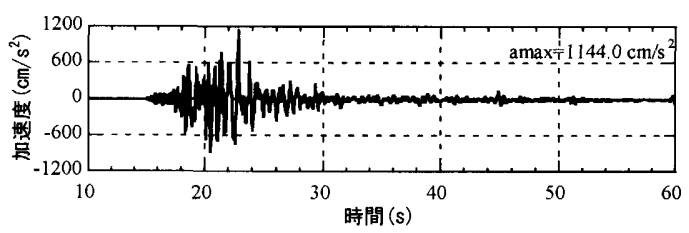

(b)新潟県中越地震小千谷市 NS

図 2 観測記録

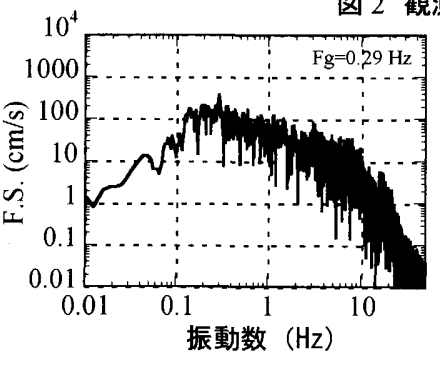

(a) 十勝沖地震 NS

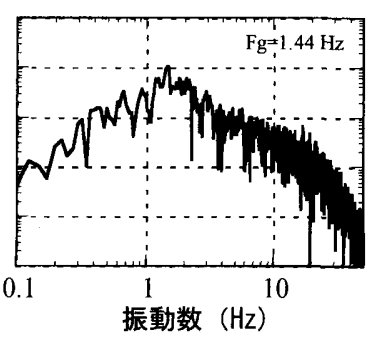

（b）新潟県中越地震 NS
図 3 フーリエスペクトル

(a)図が無次元振幅包絡線関数 $\sigma_{f} / \sigma_{f \max }$ 、(b)図が卓越振動数 $\omega_{g}$ 、 (c)図がスペクトルの形状係数 $h_{g}$ である。図 3 より、 $\sigma_{f}$ は強震付近 
を中心に単峰型を示し、 $\omega_{g}$ は Tomakomai 型の場合、単調減少する のに対し、Ojiya 型の場合 $\omega_{g}$ は 10〜25rad/s を変動することが判る。 また、形状係数 $h_{g}$ の値は異なるが、類似した傾向を示している。
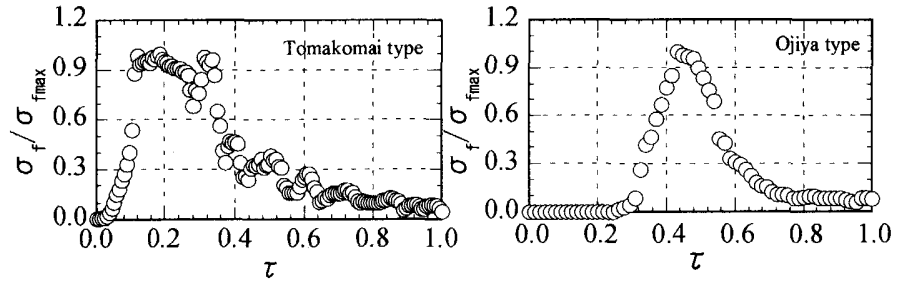

(a)無次元振幅包絡線関数
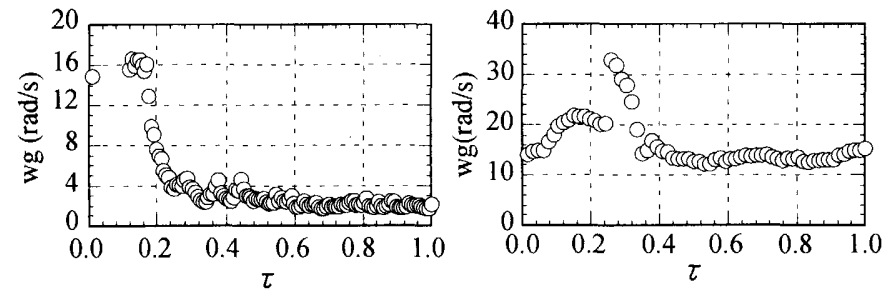

(b)卓越振動数
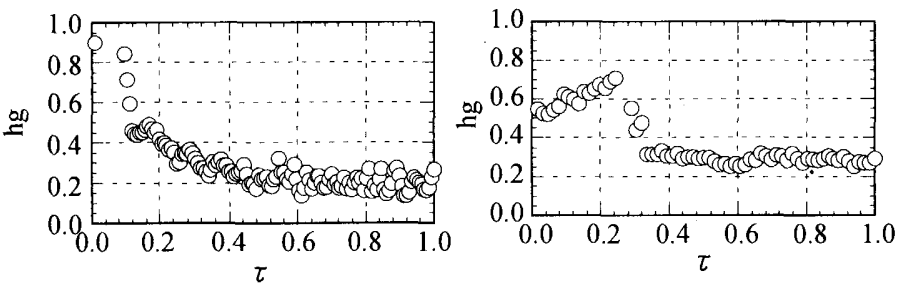

(c)形状係数

図 4 非定常ランダム入カモデル

\section{4. 解析手法}

4.1 非線形粘性ダンパーの定式化 ${ }^{4)}$ 之統計的等価線形化法 ${ }^{8)}$

図 5 には、NV ダンパーの荷重・変形関係が描かれている。ここで、 $\dot{u}_{1}, \dot{u}_{c r}$ は夫々粘性ダンパーの速度応答、速度応答の閾值である。 NV ダンパーの減衰力 $F$ は、次式のように表現できる。

$$
\begin{aligned}
& F=c^{\prime} \phi\left(\dot{u}_{1}\right) \\
& \phi\left(\dot{u}_{1}\right)= \begin{cases}\dot{u}_{1} \quad: & \left|\dot{u}_{1}\right| \leq \dot{u}_{c r} \\
\dot{u}_{c r} & : \quad \dot{u}_{1}>\dot{u}_{c r} \\
-\dot{u}_{c r} & : \quad \dot{u}_{\mathrm{I}}<-\dot{u}_{c r}\end{cases}
\end{aligned}
$$

ここで、 $\phi\left(\dot{u}_{1}\right)$ はダッシュポット要素の速度に関する非線形関数を 表す。(6)式を単位階段関数 $s($.$) で表現すると次式となる。$

$\phi\left(\dot{u}_{1}\right)=\dot{u}_{1}\left\{s\left(\dot{u}_{1}+\dot{u}_{c r}\right)-s\left(\dot{u}_{1}-\dot{u}_{c r}\right)\right\}+\dot{u}_{c r}\left\{s\left(\dot{u}_{1}-\dot{u}_{c r}\right)-s\left(-\dot{u}_{1}-\dot{u}_{c r}\right)\right\}(7)$

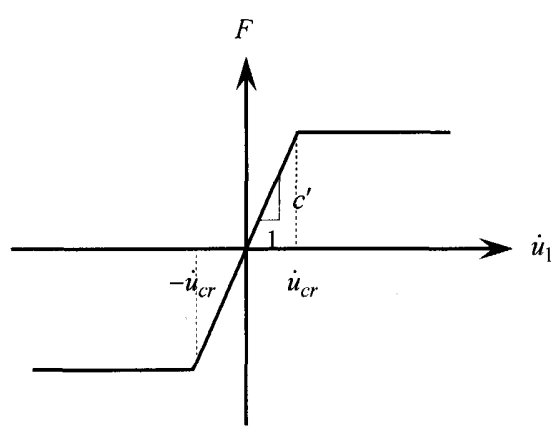

図 $5 \mathrm{NV}$ ダンパーの荷重·変形関係

(7)式に $\dot{u}_{1}$ の分布の正規性を前提とする統計的等価線形化法を適
用すれば次式のように表現できる。

$$
\phi\left(\dot{u}_{1}\right) \cong c_{d} \dot{u}_{1} \quad ; \quad c_{d}=E\left[\frac{\partial \phi}{\partial \dot{u}_{1}}\right]=\operatorname{erf}\left(\frac{\dot{u}_{c r}}{\sqrt{2} \sigma_{\dot{u}_{1}}}\right)
$$

ここで、 $c_{d}, \sigma_{\dot{u}_{1}}$ は夫々ダンパーの等価線形化係数、速度応答の r.m.s. 值である。

\section{2 免震系モデルの基礎運動方程式の誘導}

ランダム地震入力を受ける BIS モデルの任意 $\mathrm{i}$ 層及び免震層の運 動方程式は、図 1 を参考にすると次式のように与えられる。 i 層 :

$$
\left.\begin{array}{l}
m_{i}\left(\ddot{u}_{1}+\cdots+\ddot{u}_{i}\right)+c_{i} \dot{u}_{i}-c_{i+1} \dot{u}_{i+1}+r_{i} k_{i} u_{i}-r_{i+1} k_{i+1} u_{i+1} \\
+\left(1-r_{i}\right) k_{i} g_{1 i}-\left(1-r_{i}\right) k_{i+1} g_{1 i+1}=-m_{i} f
\end{array}\right\}
$$

免震層

$$
\left.\begin{array}{l}
m_{i} \ddot{u}_{1}-c_{2} \dot{u}_{2}+r_{1} k_{1} u_{1}-r_{2} k_{2} u_{2}+\left(1-r_{1}\right) k_{1} g_{11}-\left(1-r_{2}\right) k_{2} g_{12} \\
=-m_{1} f \\
\dot{y}_{1}=g_{21} \\
f=\ddot{z}+\ddot{w} \quad: \quad \ddot{z}+2 h_{g} \omega_{g} \dot{z}+\omega_{g}^{2} z=-\ddot{w}
\end{array}\right\}
$$

一方、BISNV モデルの運動方程式について、任意 $\mathrm{i}$ 層のそれは(9) 式と同じであり、免震層は次式のように表現できる。

$$
\left.\begin{array}{l}
m_{i} \ddot{u}_{1}+c_{1} \phi\left(\dot{u}_{1}\right)-c_{2} \dot{u}_{2}+r_{1} k_{1} u_{1}-r_{2} k_{2} u_{2}+\left(1-r_{1}\right) k_{1} g_{11} \\
-\left(1-r_{2}\right) k_{2} g_{12}=-m_{1} f \\
\dot{y}_{1}=g_{21}
\end{array}\right\}
$$

(9),(10)及び(12)式を一般的なマトリクス形式で表現すると次式とな る。

BIS モデル :

$$
\left.\begin{array}{l}
\{\ddot{u}\}+[\widetilde{c}]\{\dot{u}\}+[\widetilde{k}]\langle u\}+\left[\widetilde{k}^{\prime}\right]\left\{g_{1}\right\}=-\left\{1^{\prime}\right\} f \\
\{\dot{y}\}=\left\{g_{2}\right\}
\end{array}\right\}
$$

BISNV モデル :

$$
\left.\begin{array}{l}
\left.\{\ddot{u}\}+[\tilde{c}]\{\dot{u}\}+[\tilde{k}]\{u\}+\left[\tilde{k}^{\prime}\right]\left\{g_{1}\right\}+\left[\tilde{c}^{\prime}\right]\{\phi\}=-\left\{1^{\prime}\right\} f\right\} \\
\{\dot{y}\}=\left\{g_{2}\right\}
\end{array}\right\}
$$

ここで、 $\{u\},\{y\}$ は免震系の層間変位及びクーロン素子の層間変位ベ クトルで、 $[\tilde{c}]\left(=[J]^{-1}[m]^{-1}[c]\right),[\tilde{k}]\left(=[J]^{-1}[m]^{-1}[k]\right)$ は系の粘性减衰、剛 性に関するマトリクスで、 $[J]^{-1}$ は層間座標系に変換する逆マトリク スである。[ $\left.\tilde{k}^{\prime}\right]$ は Bi-linear 型履歴特性を示す塑性剛性に関するマトリ クスで、 $[\vec{c}\}\{\phi\}$ は夫々 NV ダンパーの粘性减衰係数に関するマトリ クスと非線形関数ベクトルである。また、 $\left\{g_{1}\right\},\left\{g_{2}\right\}$ は免震層及びフ レームの Bi-linear 型履歴要素を構成するクーロン素子の変位と速度 に関する非線形関数ベクトル、\{1'\}は最下段エレメントのみが 1 、 その他は 0 のベクトルで、 $f, z, \ddot{w}$ は夫々構造物への地震入力、表層 地盤の相対変位、基盤へ入力されるホワイトノイズである。

それらの非線形関数 $\left\{g_{1}\right\},\left\{g_{2}\right\}$ の分布の正規性を前提とする統計的 等価線形化法を適用すれば、次式のように線形近似される。

$$
\left.\begin{array}{l}
\left\{g_{1}\right\} \cong\left[c_{1}\right]\{\dot{u}\}+\left[c_{2}\right]\{y\} \\
\left\{g_{2}\right\} \cong\left[c_{3}\right]\{\dot{u}\}+\left[c_{4}\right]\{y\}
\end{array}\right\}
$$

ここで、 $\left[c_{1}\right] \sim\left[c_{4}\right]$ は等価線形化係数に関するマトリクスで、その係 数は文献 8)を参照されたい。

(8)、(15)式を夫々(13)、(14)式に代入すると、BIS、BISNV モデル の運動方程式は最終的に次式となる。 
BIS モデル :

$\left.\left.\left.\{\ddot{u}\}+(\tilde{c}]+[\tilde{k}] c_{1}\right]\right)\{\dot{u}\}+[\tilde{k}]\{u\}+[\tilde{k}] c_{2}\right]\{y\}=-\left\{1^{\prime}\right\} f$

BISNV モデル :

$$
\left.\left.\{\ddot{u}\}+\left([\tilde{c}]+[\tilde{k}]_{c_{1}}\right]+\left[\tilde{c} \mathbf{c} c_{5}\right]\right)\{\dot{u}\}+[\tilde{k}]\{u\}+[\tilde{k}] c_{2}\right]\{y\}=-\left\{1^{\prime}\right\} f
$$

ここで、 $\left[c_{5}\right]$ は NV ダンパーの等価線形化係数に関するマトリクス で、最下層は $c_{d}$ 、その他は全て0の要素を示寸。

状態変数として、 $\{U\}^{T}=\{\{u\},\{\dot{u}\},\{y\}, z, \dot{z}\}^{T}$ を選ぶと、(11)、(15)及び (16)、(17)式の各運動方程式は次の 1 階常微分方程式で書換えられる。

$$
\begin{aligned}
& \frac{d}{d t}\{U\}=[a]\{U\}+\{b\} \ddot{w} \\
& \Leftrightarrow \quad \dot{U}_{j}=\sum_{i=1}^{\pi} a_{j i} U_{i}+b_{j} \ddot{w}
\end{aligned}
$$

ここで、 $\tilde{n}(=3 n+2)$ は系の運動を規定するのに必要な状態変数の数 の最大值、 $n$ は質点数、 $a_{j i}, b_{j}$ は夫々、系の剛性, 粘性減衰及び地 震入力の卓越振動数 $\omega_{g}$ 、スペクトルの形状係数 $h_{g}$ により規定され る係数ならびに地震入力強度に関する係数である。

(18)式より、 $E[\cdot]$ を平均演算子として、系の統計的 2 次モーメント 㐫答 $E\left[U_{i} U_{j}\right]=m_{i j}$ は、非定常確率過程の場合、次の常微分方程式の 解として与えられる。

$$
\left.\begin{array}{l}
\dot{m}_{i j}=\sum_{l=1}^{\pi}\left(a_{i l} m_{l j}+a_{j l} m_{l i}\right) ; i=1 \sim \tilde{n}-1, j=i \sim \tilde{n} \\
: m_{\tilde{n} \tilde{n}}=\left(\sigma_{f}^{2}-4 h_{g} \omega_{g}^{3} m_{\tilde{n}-1 \tilde{n}}-\omega_{g}^{4} m_{\tilde{n}-1 \tilde{n}-1}\right) / 4 h_{g}^{2} \omega_{g}^{2}
\end{array}\right\}
$$

また、定常確率過程 $\sigma$ 場合、 $\dot{m}_{i j}=0$ となり、 $m_{i j}=M_{J}(\mathrm{~J}=1 \sim \mathrm{N})$ と 表記すると、最終的に次式の連立方程式の解 ${ }^{9}$ として与えられる。

$$
[A]\{M\}=\{B\} \sigma_{f}^{2}
$$

ここで、2 次モーメント态答 $\mathrm{M}$ の助変数 $J=(i-1)(\tilde{n}-i / 2), \quad N=$

$(\tilde{n}-1)(\tilde{n}+2) / 2$ である。

\section{3 免震系の地震信頼性評価}

構造物が地震入力を受けたとき、その継続時間 $T_{d}$ 間で、変位応答 が動的不安定を意味する閾值を超過する確率を破壊確率、これに対 応して闇值に達しない確率を残存確率、つまり地震信頼性と定義で きる。この評価法は、浅野が既報 ${ }^{10)}$ で開発しており、本論もこれに 準拠し、ここでは簡単に述べることにする。

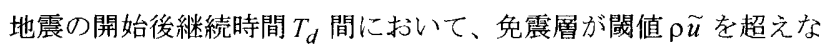
い残存確率 $R_{1}(t)$ つまり地震信頼性 $R_{\mathrm{l}}\left(T_{d}\right)$ は次式のように与えられ る。

$$
R_{1}\left(T_{d}\right)=\exp \left\{-\int_{0}^{T_{d}} h_{f_{1}} d t\right\}
$$

ここで、 $h_{f_{1}}$ は初通過破壊率関数で、次式のように与えられる。

$$
\begin{aligned}
& h_{f_{1}}=\frac{\sqrt{1-s_{u_{1} \dot{u}_{1}}^{2}} \sigma_{\dot{u}_{i}}}{\pi \sigma_{u_{1}}} \exp \left(-\frac{\rho^{2} \tilde{u}^{2}}{2\left(1-s_{u_{1} \dot{u}_{1}}^{2}\right) \sigma_{u_{1}}^{2}}\right) \\
& +\frac{s_{u_{1} \dot{u}_{1}} \rho \tilde{u} \sigma_{\dot{u}_{i}}}{\sqrt{2 \pi} \sigma_{u_{1}}^{2}} \exp \left(-\frac{\rho^{2} \tilde{u}^{2}}{2 \sigma_{u_{1}}^{2}}\right) \operatorname{erf}\left(-\frac{s_{u_{1} \dot{u}_{1}} \rho \tilde{u}}{\sqrt{2\left(1-s_{u_{1} \dot{u}_{1}}^{2}\right) \sigma_{u_{i}}}}\right)
\end{aligned}
$$

特に、定常確率猧程の場合、 $s_{\mu_{1} 1_{1}}=0$ となり、(22)式は次式となる。

$$
h_{f_{1}}=\frac{\sigma_{u_{1}}}{\pi \sigma_{u_{i}}} \exp \left(-\frac{\rho^{2} \tilde{u}^{2}}{2 \sigma_{u_{1}}^{2}}\right)
$$

(23)式を(21)式に代入すると最終的に地震信頼性 $R_{1}\left(T_{d}\right)$ 江次式と
なる。

$$
R_{1}\left(T_{d}\right) \cong \exp \left\{-\frac{T_{d} \sigma_{\dot{u}_{1}}}{\pi \sigma_{u_{1}}} \exp \left(-\frac{\rho^{2} \tilde{u}^{2}}{2 \sigma_{u_{1}}^{2}}\right)\right\}
$$

免震系全体の地震信頼性 $R\left(T_{d}\right)$ を(24)式を各層の信賴性の総和と して表現することは可能である。しかし、過大入力時の上部構造物 の最大変位応答が一部、塑性域に入る可能性はあるが、殆どの場合、 既往の解析例で弹性域以内であることは明らかである。従って、本 論では、免震層に関する地震信頼性に限定している。

\section{4 免震系の性能指定型最適パラメータの評価}

$100 \mathrm{~cm} / \mathrm{s}$ 入力時の BISNV モデルでの免震層の応答を BIS モデルの それに耐震安全性と居住性に関する性能要求係数 $\rho$ を乗じた応答に 一致させるNV ダンパーの最適パラメータを推定するために、次式 のような 2 種類の目的関数を定義する。

$$
\begin{aligned}
& J_{s}=\left(\sigma_{u_{1}} / \rho \sigma_{\bar{u}_{1}}-1\right)^{2} \\
& J_{c}=\left(\sigma_{\alpha_{1}} / \rho \sigma_{\bar{\alpha}_{1}}-1\right)^{2}
\end{aligned}
$$

ここで、 $\sigma_{u_{1}}, \sigma_{\alpha_{1}}, \sigma_{\bar{u}_{1}}, \sigma_{\bar{\alpha}_{1}}$ は夫々 $100 \mathrm{~cm} / \mathrm{s}$ 入力時の BISNV モデルでの 任意 $\mathrm{i}$ 層の層間变位応答と絶対加速度応答の r.m.s.值と、BIS モデル のそれらである。また、 求係数である。(25)、(26)式の各応答の r.m.s 值忙、(20)式の 2 次モー メント応答により求める。

\section{5. 解析パラメータ \\ 5.1 地震入カモデル}

表 1 は土勝沖地震 NS 成分、新潟県中越地震 NS、神戸地震 NS 成分、El Centro 地震 NS 成分、Taft 地震 EW 成分及び八戸地震 NS 成 分の最大速度を $100 \mathrm{~cm} / \mathrm{s}$ とし、その強震部分を基に計算したランダ 厶八力の非定常パラメータ ${ }^{6)}$ の平均值を示している。2003 年十勝沖 地震は「やや長周期」成分を含んだ地震動で、継続時間が非常に長 いが、最大加速度は大きくないのが特徵である。本論では、免震系 の最適設計を検討する上で入力地震動の最大速度を一定にしている。 この点については今後十分な議論が必要であると考えている。

表 1 ランダム地震入カモデル

\begin{tabular}{l|c|c|c}
\hline & $\sigma_{f}\left(\mathrm{~cm} / \mathrm{s}^{2}\right)$ & $\omega_{g}(\mathrm{rad} / \mathrm{s})$ & $h_{g}$ \\
\hline Tomakomai 型 & $266.5 / 3$ & 2.94 & 0.323 \\
\hline Ojiya 型 & $1173.6 / 3$ & 16.24 & 0.400 \\
\hline Kobe 型 & $906.0 / 3$ & 12.90 & 0.300 \\
\hline El Centro 型 & $1022.0 / 3$ & 17.00 & 0.470 \\
\hline Taft 型 & $992.0 / 3$ & 13.13 & 0.680 \\
\hline Hachinohe 型 & $660.0 / 3$ & 7.78 & 0.850 \\
\hline
\end{tabular}

\section{2 構造物モデル}

構造物モデルは夫久、11 質点免震系モデルを想定し、免震系モデ ルに関する標準パラメータを次のように設定する。

(1)上部構造物は、表 2 に示す 10 質点系モデルで、 1 次固有周期 $T_{1}$ は 1.0 秒、 1 次减衰定数 $h_{1}$ は $2 \%$ の初期剛性比例型、Bi-linear 型履歴特 性の第 2 分枝勾配は $r_{i}=r_{i}^{\prime}=0.1$ とする。階高、質量は夫々 $400(\mathrm{~cm})$ 、 $12.5\left(\mathrm{kN} \cdot \mathrm{s}^{2} / \mathrm{cm}\right)$ で各層一様とする。弾性剛性分布は耐震規準に基づ き、各層の層間変位応答分布が一様になる様に決定した。(2)各モデ ルの免震層は、図 6 に示寸ような積層ゴムと鋼棒ダンパーで構成さ 
れ、復元力特性は Bi-linear 型を示す。免震系の 1 次固有周期は 4.0 秒とし、鋼棒ダンパーの初期剛性 $k_{d}$ 、降伏強度 $\alpha Q_{1}$ は夫々積層ゴム の剛性 $k_{I}$ の 10 倍、免震層上部の構造物重量の 1 25\% とする。(3) $\mathrm{NV}$ ダンパーの粘性减衰倸数 $c^{\prime}$ は 8 800 $(\mathrm{kN} \cdot \mathrm{s} / \mathrm{cm})$ とし、速度応答 の閾値 $\dot{u}_{c r}$ は $10 \mathrm{~cm} / \mathrm{s}$ とする。

\begin{tabular}{c|c}
\multicolumn{2}{c}{ 表 2 上部構造物 } \\
\hline 階 & 層剛性 $(\mathrm{kN} / \mathrm{cm})$ \\
\hline 10 & 6785.2 \\
\hline 9 & 10819.7 \\
\hline 8 & 14177.5 \\
\hline 7 & 17055.7 \\
\hline 6 & 19529.9 \\
\hline 5 & 21641.3 \\
\hline 4 & 23411.4 \\
\hline 3 & 24855.9 \\
\hline 2 & 25985.7 \\
\hline 1 & 26807.6 \\
\hline
\end{tabular}

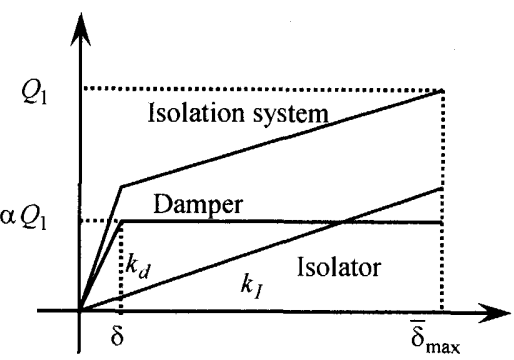

図 6 免震層の荷重·变形関係

\section{6. 数值解析例}

\section{1 免震層の設計}

本論では、免震系モデルの 1 次固有周期を 4.0 秒になるように固 有值解析を実施し、収束計算により積層ゴムの剛性を決定する。そ の結果を表 3、4 に示寸。一例として鋼棒ダンパーの降伏強度レベル 及び初期剛性比は夫々 $\alpha=0.10, \beta=10$ である。

\section{表 3 免震層の設計}

\begin{tabular}{c|c|c|c}
\hline $\begin{array}{c}\text { 初期剛性 } \\
(\mathrm{kN} / \mathrm{cm})\end{array}$ & $\begin{array}{c}2 \text { 次剛性 } \\
(\mathrm{kN} / \mathrm{cm})\end{array}$ & $\alpha \mathrm{Q}(\mathrm{kN})$ & $\delta(\mathrm{cm})$ \\
\hline 3919.2 & 356.3 & 13467.7 & 3.78 \\
\hline
\end{tabular}

表 4 固有値解析結果 単位: $\mathrm{s}$

\begin{tabular}{c|c}
\hline 1 次 & 4.000 \\
\hline 2 次 & 0.575 \\
\hline 3 次 & 0.308 \\
\hline 4 次 & 0.213 \\
\hline 5 次 & 0.164 \\
\hline
\end{tabular}

\section{2 免震系の地震信頼性評価}

本節では、入力地震動レベルに対し、BIS モデルの地震信頼性（以 下、SR）の低下の影響を検討する。図 7 には、入力地震動を Tomakomai 型ランダム入力とし、入力地震動レベルを $5 \sim 150 \mathrm{~cm} / \mathrm{s}$ まで $5 \mathrm{~cm} / \mathrm{s}$ 刻 みに変動させ、免震層の降伏耐力レベル $\alpha=0.05,0.075,0.1$ とした場 合の 4.3 節の(24)式の地震信頼性 SR が描かれている。

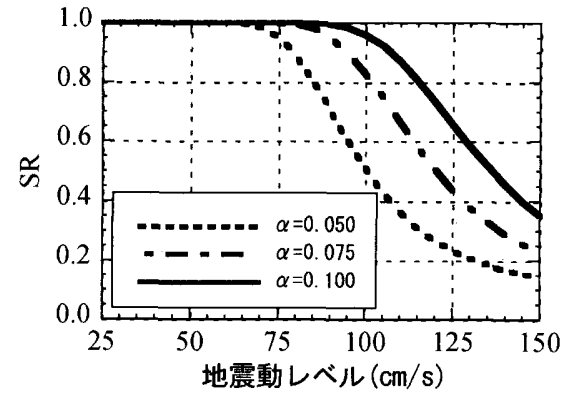

図 7 入力地震動レベルに対する地震信頼性
図 7 より、地震信頼性 SR は降伏耐カレベル $\alpha$ の選択により異な るが、 $\alpha=0.05$ の場合、 $70 \mathrm{~cm} / \mathrm{s}$ を超えると SR は 1.0 以下になり急激 に低下することが判る。これは、免震層の最大変形量が間値を超え て、不安定な状況に陥る可能性があると言える。同様に、 $\alpha=0.075$, 0.1 の場合、夫々 $85 、 95 \mathrm{~cm} / \mathrm{s}$ で闇值を超過していることが判る。しか し、免震層の降伏耐力が増加するにつれて、履歴減衰効果で免震層 の変形を低減することができ、閾值を超過する地震動レベルが右側 に移行したものと考えられる。

6.3 免震層の性能指定型最適パラメータの推定

1）地震信頼性解析に基づく鋼棒ダンパーの最適降伏耐カレベルの 評価

図 8 には、入力地震動を Tomakomai 型、Ojiya 型ランダム入力と し、鋼棒ダンパーの降伏耐カレベル $\alpha=0.01 \sim 0.25$ まで 0.01 刻みに 変動させ、BIS モデルの SR が描かれている。ここで、(24)式中の性 能要求係数 $\rho$ 、免震層の閾値 $\tilde{u}$ 注夫々 1.0 、積層ゴムの性能保障限界 值(せん断歪 $300 \%$ )の $60.9 \mathrm{~cm}$ とする。図 8 より、鋼棒ダンパーの降 伏耐力が増加するにつれて、SR は非線形的に增加し、1.0に漸近し ていくことが判る。つまり、免震層の閾値を超える確率が低下し、 安全を意味する。2 種類のランダム入力で $\mathrm{SR}=0.98$ を満足する最適 解は、夫々 $0.105 、 0.13$ である。これは、免震構造を設計する際、上 部構造物重量の $10 \%$ を示しているので、現実的に非常に困難と言え よう。以上の結果より、次項以降、鋼棒ダンパーの降伏耐力は免震 構造の実施設計で使用される範囲とし、その不足分を NV ダンパー の粘性隇衰に期待し、その最適パラメータを推定する。

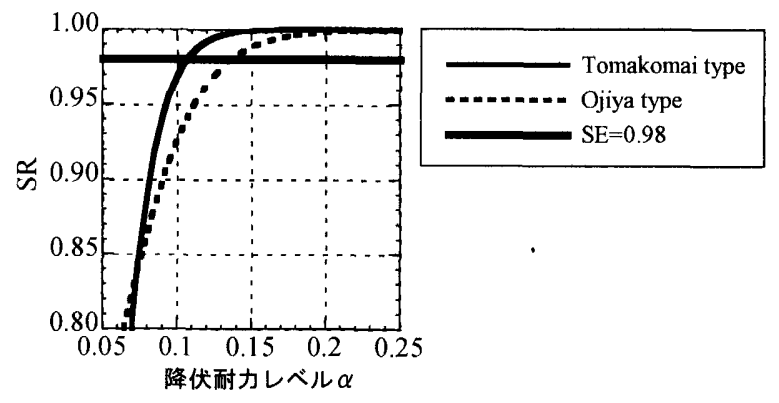

図 8 鋼棒ダンパーの降伏耐カレベルに対する地震信頼性 2) NV ダンパーの最適粘性減衰係数の評価

図 9 には、入力地震動を Tomakomai 型、Ojiya 型ランダム入力と し、鋼棒ダンパーの降伏耐カレベル $\alpha=0.075 、 N V$ ダンパーの粘性 減衰係数 $c^{\prime}=8.0 \sim 800(\mathrm{kN} \cdot \mathrm{s} / \mathrm{cm})$ まで $8(\mathrm{kN} \cdot \mathrm{s} / \mathrm{cm})$ 刻みに変動させ、 性能要求係数 $\rho=0.6 \sim 0.8$ (せん断歪 $240 \sim 320 \%$ 程度に対応）とした 場合の SR 及び(25),(26)式の 2 種類の目的関数 $J_{s}, J_{c}$ が描かれている。 ここで、(a)図が SR、(b)図が $J_{s} 、$ (c)図が $J_{c}$ である。本論では、地 震信頼性解析に基づく NV ダンパーの最適粘性減衰係数 $c_{o p t}^{\prime}$ は、免 震構造の現実性を考慮して、SR=0.98 となる点を最適解として定義 する。(a)図より、地震信頼性 SR は、 $c^{\prime}$ の変動に対して非線形的に 増加し、SR=1.0に漸近していくことが判る。性能要求倸数 $\rho$ が小さ くなるにつれて、最適粘性減衰係数 $c_{o p t}^{\prime}$ は大きくなることが判る。 (b)図より、目的関数 $J_{s}$ は、 $c^{\prime}$ の変動に対して鋭敏であり、 $J_{s}$ を最 小にする最適粘性隇衰係数 $c_{o p t}^{\prime}$ が存在し、。が大きくなるにつれて は小さくなることが判る。しかし、最適パラメータは Tomakomai 型 
と Ojiya 型ランダム入力では若干異なる。(c)図より、 $J_{c}$ は $c^{\prime}$ の変動 に対して極めて鈍感で、図 7 の結果から判るように、鋼棒ダンパー の履歴減衰効果でかなり加速度応答を低減しているために、NVダン パーの粘性减衰を付加しても、 $J_{s}$ ほどの明確な極值が存在しない。 夫々の指標での最適粘性减衰係数の結果を表 5-1、5-2 に示す。以上

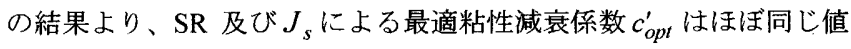
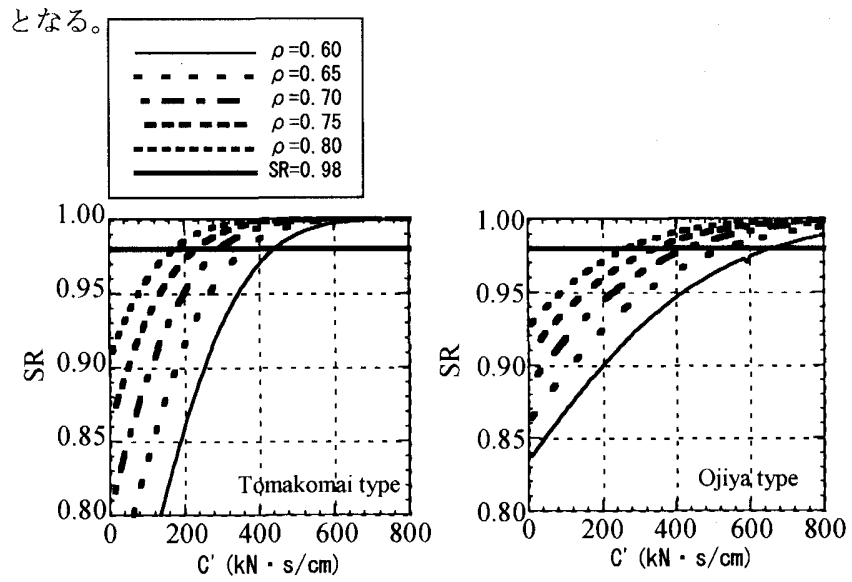

(a) 地震信頼性 SR
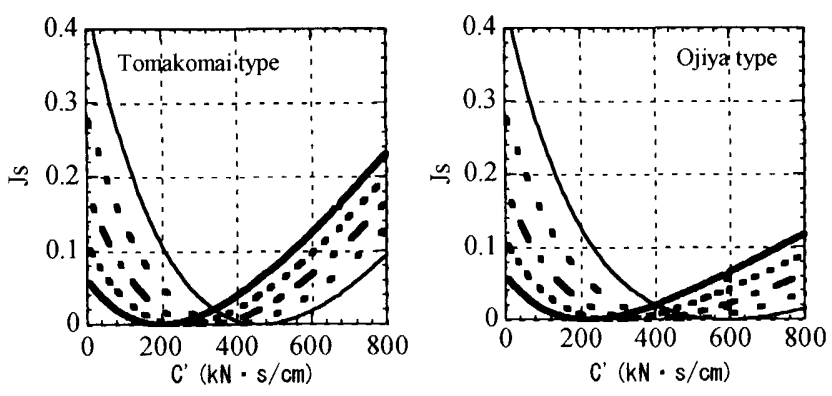

(b) 目的関数 Js
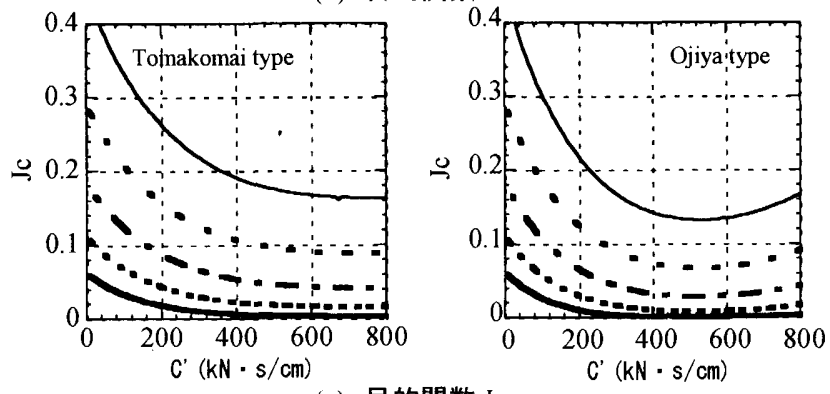

(c) 目的関数 Jc

図 $9 \mathrm{NV}$ ダンパーの粘性減衰係数に対する地震信頼性·目的関数

表 5-1 NV ダンパーの最適粘性減衰係数(Tomakomai 型)

\begin{tabular}{c|c|c|c}
\hline$\rho$ & SR & JS & Jc \\
\hline 0.60 & 440 & 464 & 672 \\
\hline 0.65 & 368 & 392 & 672 \\
\hline 0.70 & 296 & 320 & 672 \\
\hline 0.75 & 232 & 256 & 672 \\
\hline 0.80 & 168 & 200 & 672 \\
\hline
\end{tabular}

表 5-2 NV ダンパーの最適粘性減衰係数 (Ojiya 型)

\begin{tabular}{c|c|c|c}
\hline$\rho$ & SR & Js & Jc \\
\hline 0.60 & 584 & 656 & 528 \\
\hline 0.65 & 472 & 536 & 528 \\
\hline 0.70 & 376 & 432 & 528 \\
\hline 0.75 & 296 & 344 & 528 \\
\hline 0.80 & 216 & 264 & 528 \\
\hline
\end{tabular}

単位 $: \mathrm{kN} \cdot \mathrm{s} / \mathrm{cm}$
6.4 入力地震動特性の差異が NV ダンパーの最適粘性減衰係数に及 ぼす影響

本節では、入力地震動特性の差異が NV の最適粘性減衰係数 $c_{o p t}^{\prime}$ に 対して、どの程度影響するかを検討する。入力地震動モデルは、 Tomakomai、Ojiya 型に加えて、Kobe 型、El Centro 型、Taft 型、Hachinohe 型ランダム入力とする。図 10 には、地震信頼性 SR 及び目的関数 $J_{s}$, $J_{c}$ に基づき得られた最適粘性減衰倸数 $c_{o p t}^{\prime}$ が性能要求係数 $\rho$ に対 して描かれている。図 10 より、SR 及び $J_{s}$ の場合、Tomakomai 型入 力に対する最適パラメータ $c_{o p t}^{\prime}$ は他のランダム入力のそれと若干異 なることが判る。一方、 $J_{c}$ の場合、各ランダム入力での最適パラメ 一夕は異なることが判る。これは、図 8(c)に示したように、目的関 数の変動が極めて鈍感であるためと推察される。

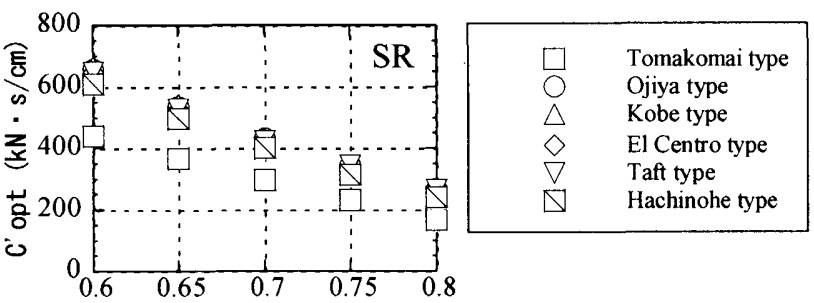

性能要求係数 $\rho$

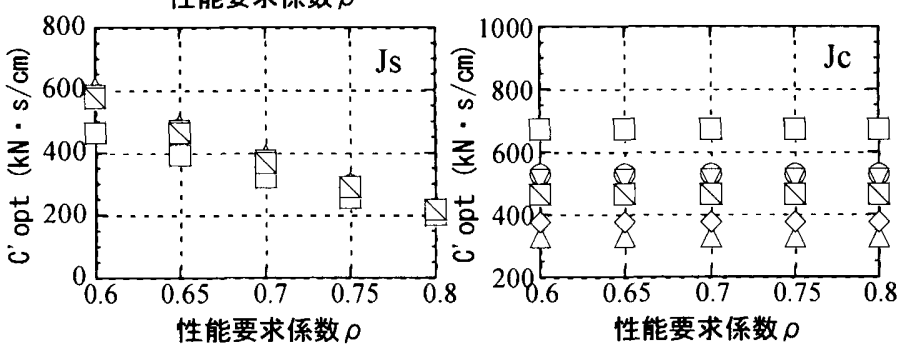

図 10 入力地震動の差異に対するNVダンパーの最適粘性隇衰係数

$6.5 \mathrm{NV}$ ダンパーの最適粘性滅衰係数が入力地震動レベルに及ぼす 影響

本節では、6.3 節 2)項で得られた NV ダンパーの最適粘性減衰係数 $c_{o p t}^{\prime}$ が入力地震動レベルに対して、どのような影響を及ぼすかを地 震信頼性 SR 及び免震層の最大変位応答の観点から検討する。

図 11 には、免震層の降伏耐力レベル $\alpha=0.075$ 、ランダム入力モ デルを Tomakomai 型、表 5.1 に示した SR を規範にした性能要求係 数 $\rho=0.6$ に対する最適粘性減衰係数 $c_{o p t}^{\prime}=440 \mathrm{kN} \cdot \mathrm{s} / \mathrm{cm}$ とし、入力 地震動レベルを $25 \sim 150 \mathrm{~cm} / \mathrm{s}$ まで $5 \mathrm{~cm} / \mathrm{s}$ 刻みに変動させた場合の地 震信頼性 $\mathrm{SR}$ 及び免震層の最大変位応答 $u_{1 \max }$ が描かれている。
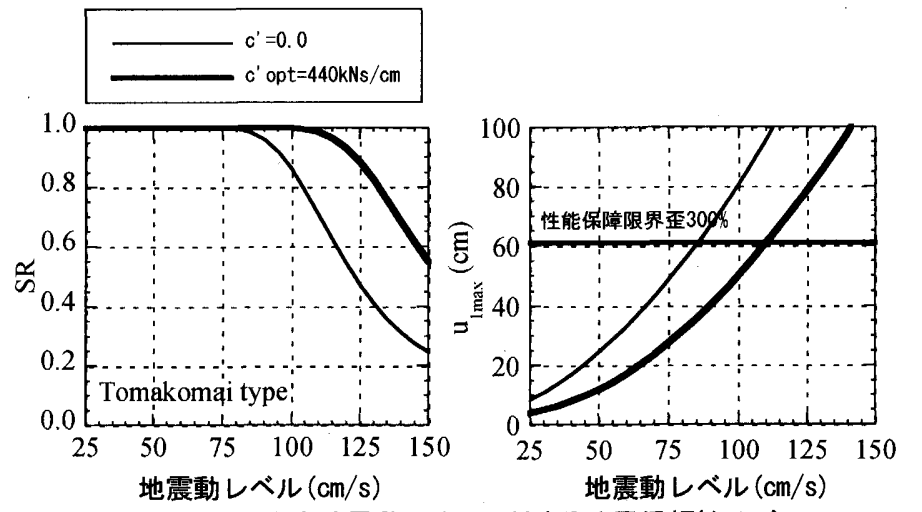

図 11 入力地震動レベルに対する地震信頼性及び 免震層の最大变位応答 
図 11 より、ダンパーを付加しない BIS モデルでは、入力地震動レ ベルが増加すると、 $90 \mathrm{~cm} / \mathrm{s}$ 付近から SR が急激に低下するのに対し、 BISNV モデルでは、 $115 \mathrm{~cm} / \mathrm{s}$ 付近まで SR は 1.0 であり、それ以後、 ゆるやかに低下寸ることが判る。これは、免震層の最大変位応答図 が示すように、積層ゴムの性能保障限界值つまり、300\%歪を超える 地震動レベルが夫々のモデルで異なり、最適なダンパーを付加する ことで、 $115 \mathrm{~cm} / \mathrm{s}$ 付近まで $300 \%$ 歪を超えることはない。すなわち、 本論で開発した地震信頼性を規範とする免震系の最適設計法におい て、安全のレベルが低下することは免震層に過大な変形を生じさせ ることを意味し、免震系の不安定挙動、危険度を明確に表現できる。

\section{6 免震系の 1 次固有周期の変動が NV ダンパーの最適粘性減衰係 数に及ぼす影響}

本節では、免震系の 1 次固有周期の変動が NV の最適粘性減衰係 数 $c_{o p t}^{\prime}$ に対して、どの程度影響するかを検討する。入力地震動モデ ルは、Tomakomai 型ランダム入力とする。図 12 には、免震層の降伏 耐力レベルを $\alpha=0.075 、 1$ 次固有周期が 3、4、5 秒に対し、地震信 頼性 SR に基づき得られた最適粘性減衰係数 $c_{o p t}^{\prime}$ が性能要求係数 $\rho$ に対して描かれている。図 12 より、固有周期の変動に対し、性能要 求倸数全体に亘り、最適粘性減衰係数は異なることが判る。

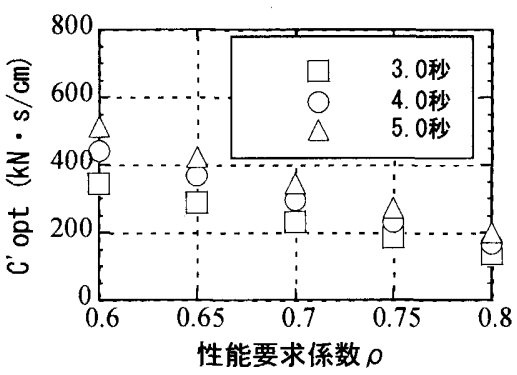

図 12 免震系の 1 次固有周期に対する NV ダンパーの 最適粘性減衰係数

\section{6 免震層の最適パラメータが地震動の非定常性に及ぼす影響}

一般に、長周期地震動に対して、超高層建築物が主要動以降の長 周期成分に共振し、長時間の摇れを経験すると言われている。しか し、免震構造物に対しても同様な傾向を示すか、本節で検証する。 ここでは、6.3 節で得られた地震信頼性を規範とする最適粘性減衰ダ ンパーを有する BISNV モデルに対して、Tomakomai 型非定常ランダ 么応答解析を実施する。図 13 は、図 9 に示した性能要求係数 $\rho=0.6$

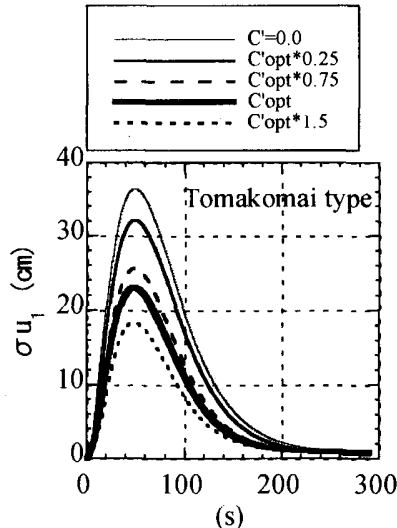

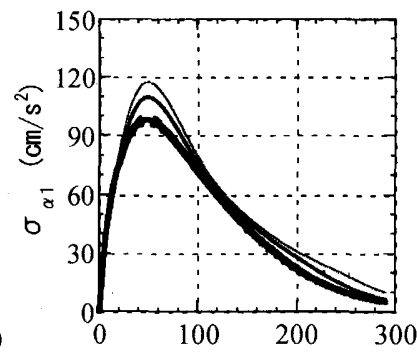

(s)
の場合の最適粘性減衰係数 $c_{o p t}^{\prime}=440 \mathrm{kN} \cdot \mathrm{s} / \mathrm{cm}$ を標準值として、そ の $25,75,100,150 \%$ をえた場合の免震層の層間変位、絶対加速度応 答の r.m.s.值の時刻歴が描かれている。図 13 より、粘性減衰係数が 增加するほど、層間変位は減少するが、加速度応答は、粘性減衰量 の変動に対してあまり変化しないことが判る。また、長周期地震動 による共振現象は見られない。これは、免震構造物の場合、時々刻々 と固有周期が変動することと、鋼棒ダンパーの履歴减衰効果及び NV ダンパーの粘性减衰効果によるものと推察される。

\section{7. 結語}

本論では、十勝沖地震(2003)、新潟県中越地震(2004)の非定常ラン ダム入力モデルを作成し、過大入力を受汁る基礎免震系の確率論的 2 次モーメント応答に基づく最適設計法を応答の最小化を規範とす る最適化手法に加えて、地震信頼性理論を規範する最適化手法を開 発した。本論の解析結果から免震系の最適設計について軽々に結論 を述べることはできないが、それらが示す工学的知見を述べる。

（1）非線形粘性ダンパーの最適粘性减哀係数 $c_{o p t}^{\prime}$ は、地震信頼性 SR 及び耐震安全性に関する目的関数 $J_{s}$ において、性能要求係数 $\rho=0.6 \sim 0.8$ の変動に対し、概ね $600 \sim 200 \mathrm{kN} \cdot \mathrm{s} / \mathrm{cm}$ となるが、 居住性に関寸る目的関数 $J_{c}$ では異なる。

（2）最適非線形粘性ダンパーを有する免震構造物では、入力地震動 レベルが $100 \mathrm{~cm} / \mathrm{s}$ 以内であれば、地震信頼性 SR は 1.0 を保つが、 $100 \mathrm{~cm} / \mathrm{s}$ 以上になると SR は急激に低下し、 $150 \mathrm{~cm} / \mathrm{s}$ で $\mathrm{SR}$ は 0.55 となる。

（3）本論の様な地震動のランダム性を考虑した確率論的地震応答 解析に基づく免震層の最適パラメータを推定する限り、入力地 震動特性がその最適パラメータに及ぼす影響は少ない。

\section{謝辞}

本論で採用しました十勝沖地震苫小牧市及び新潟県中越地震小千 谷市での観測記録は、独立行政法人防災科学技術研究所 (K-NET, KiK-net）より使用させて頂きました。ここに深く謝意を表します。

\section{参考文献}

1)Hall,J.F., et al. : Near-Source ground Motion and its Effects on Flexible Buildings, Earthquake Spectra, Vol.11,No.4, pp.569 605

2)中安誠明、中島正愛 : 過大地震下に拈浼震建物の応答と損傷、日本建築 学侌近畿支部研究報告集、第 43 号・構造系、pp.205 208、2003.6

3)中川肇 : ランダム地震入力を受ける連結制震ダンパーを有する 2 棟免震構造 物の性能指定型設計について、日本建築学会構造系論文集、第 585 号、pp.63 $\sim 69 、 2004.11$

4)中川肇、浅野幸一郎 : Maxwell 型非線形粘性ダンパーを有寸る構造物の最適 地震応答制御について、日本建築学会構造系論文集、第 542 号、pp.83〜89、 20014

5)中川肇、浅野幸一郎 : Poly-linear 型履歴ダンパーを用いた多層構造物の最適 地震応答制御について 〜 Poly-linear 型履歴ダンパーの最適剛性分布の評価 ，日本建築学会構造系論文集、第 530 号、pp.45～51、2000.4

6)Lai,S.P : Statistical characterization of strong ground motions using power spectral density function, Bulletin of Seismological Society of America, Vol.72, No.1,pp. 259 274, 1982.2

7)Tajimi,H. : A Statistical Method of Determining the Maximum Response of a Building Structure during an Earthquake, Proc. of the 2nd World Conference on Earthquake Engineering, Tokyo, Japan, Vol.Il, pp.781 797, 1960

8)浅野幸一郎:履歷系の統計的等価線形化法、日本建築学会棈造系論文報告集、 第 335 号、pp.10 14、1984.1

9)浅野幸一郎、津田憲昭: 弹性構造物の最適地震信頼性設計、日本建築学会構 造系論文報告集、第 431 号、pp.33 36、1992.1

10）金子修平、松田敏、浅野幸一郎：上町断層系想定地震動モデルによる大阪 市域を対象とした建築構造物の地震信頼性解析、日本建築学会構造系論文集、 第 530 号、pp.29 36、2000.4 